\title{
Democratization and the ALA Council
}

Members of the American Library Association will soon receive a ballot to vote on a proposed change in the bylaws of the association that would reduce the size of Council and in Editorial the process eliminate representatives on the Council from the divisions. This is one of the steps of "Democratization" recommended in the ACONDA report. This proposal was approved by the Council in Dallas.

I urge all members of ACRL to veto this change. A reduction of the size of a governing body such as the ALA Council has been recommended by advocates of change as a way of producing a less ponderous legislative group that will be speedier in taking action. The elimination of any Councilor who might bring the view of the "vested interest" of a division to Council, and the mandate to vote accordingly, is cited as a democratic move, in that the remaining Councilors will have only the total membership's interest at heart.

As a matter of fact, the process of nomination and election of a smaller ruling Council is more amenable to influence, if not control, by vested interests and hence tends to a state of decreased democratization than now pertains. As long as the Association is composed of divisions, with many views and interests, official representation on the Council of this pluralistic society must be guaranteed-even if the representatives later vote as individuals and not as Councilors for the divisions.

The malaise that many people attribute to the ALA Council is due not to its size and cormposition. Rather, it must be principally attributed to an improper construction of the hierarchy through which decisions flow toward the point of Association action, the very brief time span of conferences at which deliberations are held, and an unfortunate scheduling during the conferences of the meetings of the groups and the official hierarchy in a sequence that is out of phase with the required flow of resolutions. The whole process of mobilizing the ALA to make commitments according to members' desires and appropriate to the goals of the Associations must be reviewed. Fortunately, the Association has ordered such a study.

In any event, forcing a speeding up of deliberations tends to reduce truly democratic action. Good decisions, democratically reached, will necessarily be reached slowly if the full power of democratic procedure is invoked.

ALA is essentially a personal membership organization. As long as the members have decid- ed to form themselves into divisions within the larger framework-and all members belong to at least two divisions-there must be a guaranteed mechanism for the official mandates of these divisions for Association action to be brought to the higher deliberative forum. Division representation on Council is essential for democratic action as the Association is now structured. Guaranteed divisional representation cannot be eliminated until divisions are eliminated. It is quite possible that this will be an issue in the forthcoming study of the Association. I suggest that the goals of speedier Association action on issues important to members, in priority order as determined by members, will be gained only by a complete change of the structure of the decision-making process and the ordering of the hierarchy of groups through which decisions move. The elimination of division representation at this time, in my view, moves the point of final decision-making away from, and not toward, its proper location. It would create only another element of discontent with the Association's potential for action. Discontent leads to disaffection, and ultimately, to abandonment of the Association by many of its constituents.-Russell Shank, PresidentElect, Association of College and Research Libraries

Members should also see the remarks of Miss Peggy Sullivan on this subiect in the September issue of American Libraries.

\section{INSURANCE PLANS}

The American Library Association sponsors four group insurance plans designed for personal members and their families. These include:

Income Protection

Major Medical

Senior Hospital

Life Insurance

Detailed brochures can be obtained by writing to the Library Administration Division, American Library Association, 50 East Huron Street, Chicago, IL 60611.

\section{ACRL Membership}

July 31, 1971

July 31,1970

July 31,1969 


\section{Serving all types of libraries all over the world with all known titles.

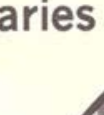

Serial subscription service without equal. Regional offices provide reliable, trouble-free service. To discuss your library's subscription service needs and learn how we can help, call us collect.

Do you have our LIBRARIAN'S HANDBOOK? This information. packed guide to over 50,000 titles is free. Write for your copy today.

826 So. Northwest Highway Bamington. III. 60010
(312) 381.2190 (312) 774.5441

Ist Ave. North at 13 th St. Birmingham, Alabama 35203 (205) 323.6351

540 Granite Street Braintree. Massachusetts 0218 (617) 843-2383/843-2384

415 Douglas Plaza Building 8226 Douglas Ave.

Dallas, Texas 75225
(214) $369.7591 / 369.7592$

(214) $369.7591 / 369$

San Francisco, California 94105 San Francisco, Cair
Room 245

Continental Terrace Building $2785 \mathrm{~N}$. Speer Boulevard colorado 80211 Cos Angeles. California 90009 Los Angeles. Cal

512 Nicollet Building

Minneapolis. Minnesota 55402 Minneapolis. Minne

EBSCO Building Rod Bank. New Jersey 07701 (201) 741.4300

5265 Port Royal Road Springfield. Virginia 2215 (703) $321.7516 / 321.9630$

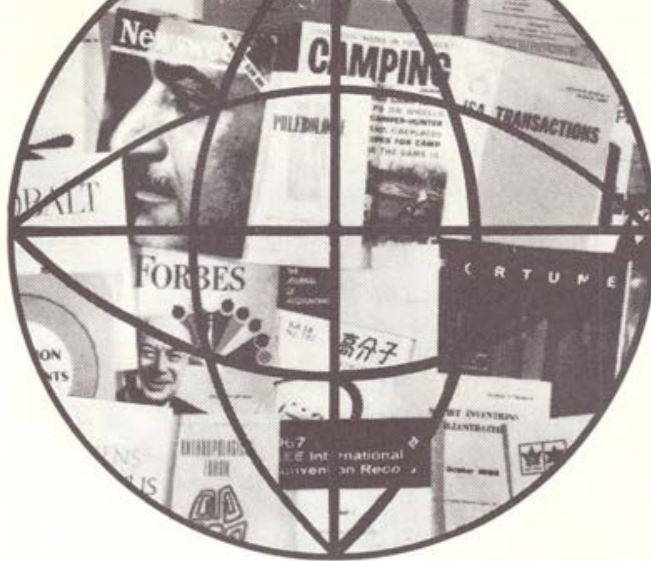

Adams Building

No. 20, 3-Chome, Nishihatchoburi Chuok ku.

Tokyo, Japan

62 Wiesbaden

Bodenstedtstrasse 6

Deutschland

(Germany)

Phone: 37.03-88

\section{EBSCO SURSCRIPTION SERVICES}

division of

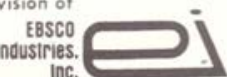

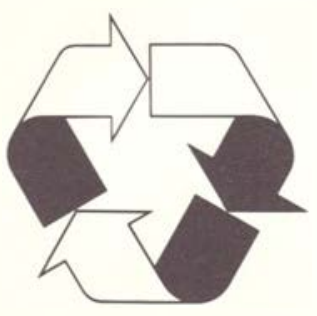

When the subject is Ecology, the serious researcher has the task of separating fact from fiction; of matching results to rhetoric.

Much has been said; little has been done, but within the paper industry, effective programs of recycling waste papers are a reality.

The July, August and September issues of CHEM 26/PAPER PROCESSING, a leading paper industry magazine, represent a unique example of real direction. These three issues are printed entirely on $100 \%$ recycled paper. They are the first of their kind in the history of paper and printing.

They are also highly informative. CHEM 26/PAPER

PROCESSING does not skirt the issues of our environmental imbalance.

They are the issues that will be discussed.

Copies for your library are available at $\$ 2.50$ per single issue or $\$ 7.00$ for the set of three, from:

Hale Publishing Company

One Bank Street

Stamford, Conn. 06901

Purchase Order or check to accompany requests. 